\title{
Guidelines to the Edge: Integrating Information Communication Technologies in Education
}

\author{
Denise Stockley \\ Queen's University, Canada
}

\begin{abstract}
Many institutions are in a state of flux in relation to the implementation and use of information communication technology (ICT) by faculty, staff, and students. Earlier research (Stockley 2002) indicates that most institutions are neither at the beginning - nor the end of the implementation continuum; rather, they are more likely to be found somewhere in the middle as institutions vary in their degree of integration. Institutions that are characterized by technological innovation are a rarity: most of us would rather read about bleeding edge technologies than experience the unwanted fallout first hand; nor can most institutions make the necessary financial commitments associated with being on the leading edge. This paper briefly visits historical aspects of technology innovations, implementation strategies and finally, focuses on approaches or guidelines to assist in getting to the edge.
\end{abstract}

Key words: Higher education. Information and communication technologies.

RESUMEN

Muchas instituciónes están en un estado de cambio contínuo en lo que se refiere a la puesta en práctica y el uso de las tecnologías de la información y la comunicación (TIC), por parte de los profesores, los administradores y los estudiantes. Investigaciónes anteriores (Stockley, 2002) han demostrodo que la mayoría de las instituciónes no están ni al principio ni al final del proceso de implementación, sino que más bien suelen encontrarse en algán punto medio del recorrido, con grados variables de integración. Las instituciónes que se caracterizan por la innovación tecnológica son una excepción: la mayoría de nosotros nos mostramos más dispuestos a leer algo sobre tecnologías de última generación, que a experimentar de primera mano los efectos indeseados; tampoco la mayor parte de las instituciónes puede asumir los compromisos financieros necesarios para estar en la vanguardia. Este artículo pasa revista brevemente a los aspectos históricos de las innovaciones tecnológicas, las estrategias de puesta en práctica y, finalmente, se centra en las tendencias o pautas que ayudan a ir situándose a la cabeza.

Descriptores: Educación superior. Nuevas technologías de la información y de la communicación.

RÉSUMÉ

De nombreuses institutions sont dans un état fluctuant sans cesse en ce qui concerne la mise en exécution et l'usage de l'informatique (ICT) par leur faculté, leur personnel et leurs étudiantes. La recherche antérieure (Stockley, 2002) indique que la plupart des institutions ne sont ni au début - ni au terme du continuum de l'implémentation; il est probable qu'elles se trouvent plus 
ou moins à mi-chemin puisque les institutions varient quant à leur degré d'intégration. Les institutions caractérisées par l'innovation technologique sont une rareté: La plupart d' entre nous préférerions lire au sujet des technologies de pointe plutôt que de faire l'expérience de première main des retombées indésirables; la plupart des institutions ne peuvent non plus se permettre les engagements économiques associés à cette position avant-gardiste. Ce papier retrace les aspects historiques des innovations technologiques, des stratégies d'implémentation et finalement il mise sur les approches ou instructions générales qui peuvent aider à s'avancer vers la pointe.

Motes-Clés: Éducation supérieure. La technologie de l'information.

\section{Technological Innovations in Education}

Technology has taken many different forms throughout the years in education, including overheads, filmstrips, movies, audiotapes, television, videos, laser-discs and, more recently, floppy-discs. Each of these innovations has had its moment in educational history when it was adopted with almost a zealot like fervour, but most have subsequently fallen out of favour.

Kearsley (1998) suggested that television revolutionized how we present and process information, but it did not revolutionize education. Quality television programs were expensive to deliver because of the technical requirements and high production costs. These high costs resulted in a wave of "candid camera" type programs, which were unsuccessful because they did not utilize the strengths of the media. (Kearsley 1998) These were often considered "talking head" programs.

Similar to these other technologies, the latest innovation of online educational technology has brought both adversaries and advocates to the forefront. For some, this form of innovation is defined "as the use of computing, media and telecommunications technologies in the process of teaching." (Bruce 1999: 5) This description will be used to define the term educational technology used throughout this paper.

Adversaries are quick to highlight that many earlier technologies are non-existent in today's classroom and that the investment by institutions in these forms of technology was a waste of already scarce resources. Dalton (1989) concluded "few technological innovations have had any real or lasting impact on the public schools, and the obstacles confronting computer-based instruction are uncannily familiar." Sliwa (1994) further cautioned that we should not assume that technology would improve the learning experience. Poole (1997) agreed that none of these earlier technologies was thought to be a driving force for change in universities.

Clark (1994a) thought that when new technology was introduced there was a tendency to ignore research about previous innovations. He stated that "we too often act as if we believe that each new delivery technology requires a new theory of learning and performance. Thus we 'reinvent the wheel' constantly but inadequately." Clark (1983, 1994b) claimed that media had no influence, and would never have any influence on learning regardless of the situation. He based this conclusion on his examination of summaries and a meta-analyses of media comparison studies. These meta-analyses provided evidence to Clark that causal relationships between media and achievement often reflect confounding variables, and he determined that the uncontrolled effects of nov- 
elty and instructional method, rather than forms of media per se, were the reasons for the studies showing any influence on learning. Clark provided an analogy that best describes his position: "media are mere vehicles that deliver instruction but do not influence student achievement any more than the truck that delivers our groceries causes changes in our nutrition. The choice of vehicle might influence the cost or extent of distributing instruction, but only the content of the vehicle can influence achievement."

In sum, Clark determined that it was not the media that encouraged learning but other variables such as instructional method. In essence, it is the teaching that promotes learning, not the media. Based on these findings Clark questioned why researchers and instructors would invest time and money in media program development.

Clark (1994a) suggested advocates were fuelled by the large advertising budgets of an industry interested in selling the hardware and software for instruction. Noble (1997) agreed with Clark and expressed a number of other concerns. First, the move towards the use of the computers in classrooms stemmed from social forces rather than educational merit. He thought that instructional delivery had become commodified through the influence of commercial vendors of hardware, software, and content. Second, in-house corporate training developers were encouraging educational uses of technology to increase their own profit margins. Third, he thought that as institutions were already suffering from cutbacks to limited resources, administrators were hoping to save money on instruction and maintenance of the physical plant of the institution. He argued that this move by administrators also provided opportunities for research collaboration with the private sector, which would increase the institution's potential to be involved with the "commodification" of instructional delivery. Hawkins (1999a) provided further cautionary advice: "the idea that technology is a panacea and that it is applicable across all types and sizes of institutions is an extraordinarily dangerous assumption."

Research on policy issues led Lewis, Smith, and Massey (1999) to express further concerns that individuals whom they interviewed tended to ignore examples of previous innovations such as radio and television that were expected to revolutionize education, but were unsuccessful. They suggested the need for government documents to provide information on how the implementations of new technologies are influenced by the lessons learned from previous experiences.

These concerns raise the question of whether newer innovations of educational technology will be able to withstand the test of time and their critics or whether they will fall by the wayside as the next innovation is developed and marketed. The response to this question is critical as most post-secondary institutions are in the middle of organizational change. Moreover to date, all Canadian post-secondary institutions have adopted web-based technology, at least in the form of web pages (AUCC 2005). And many have already developed, or are in the process of developing, a strategic plan for integrating educational technology, upgrading the infrastructure, and/or developing professional development programs that incorporate the computer in education (Stockley 2004). 


\section{The Need for Integrating Information Communication Technologies}

Historically, the role of the university has been to develop, maintain, and disseminate knowledge. This role has changed little over the last several centuries. Duderstadt (1997) argues that these roles are still the primary mission of the university; however, how we view each of these roles is changing. As a result of several simultaneous and dramatic changes, including a repositioning of the institutional role, the demographic composition of students, societal demands for research and services, the cost of instruction and research, and the availability of public support, institutions are experiencing/moving through a paradigm shift (e.g., Benjamin, Carroll, Jacobi, Krop, \& Shires 1993; Dill 1996; Ford 1996).

Decreasing financial commitments from both the federal and provincial governments in Canada challenge institutional ability to compete for resources in the educational technology market (Rossner \& Stockley 1997). Further, the politicization of educational technologies has prompted the need for organizational change in order to compete for grants and capital funds directly linked to the integration of technology in post-secondary education (Lewis, Smith, \& Massey 1999). Slack (1994) suggested that this pressure to obtain outside funding increases each year which in turn has the effect of encouraging faculty to complete research to fit these goals in order to get funding.

A further driving force behind institutional change is the shift from the industrial society towards a knowledge society. Duderstadt (1997) argued that information communication technology contributed to this shift by "dramatically changing the way we collect, manipulate, and transmit knowledge." He suggested that four themes were converging in the last decade: (a) concerns about the role that knowledge would play in determining security, prosperity, and quality of life for the individual; (b) the movement towards globalization; (c) the ease and speed that information technology allows us to obtain information; and (d) how formal social structures were being replaced through informal networks and collaborations among individuals and institutions. This same perspective is expressed in Canadian government documents that have identified key priorities in education to include terms such as just-in-time, ,job-related, and cost effective. Educational technologies are one way to support these priorities. (Lewis, Smith, \& Massey 1999).

The knowledge society movement also created an audience of learners that is more discerning about how they learn, what they learn, and when they learn it. This new awareness has resulted in some students finding sources of information that they considered was even better than those offered by their professors. These new sources may in fact challenge the inherent value of the traditional lecture (Samuels 1996).

Currently our university system is predominately geared toward an undergraduate population that attends university after completing high school. Although graduate courses and courses for the distance learner are offered, they are not considered to be the 
main focus of the institution, and courses for mid-career learners are even less apparent. Denning (1996) suggested that the development of professional programs would play a significant role in the business design of a successful university in the next century.

Further, the number of requests from industry for post-secondary institutions to provide professional development for their employees has steadily increased (Denning 1996). It is argued that the workforce of the future will not be comprised of "industrial workers" but of "knowledge workers" who are able to adapt to the changing environment quickly (Sliwa 1994). Individuals in the workforce will need to upgrade their skills constantly, and their current knowledge base needs to continually evolve to keep up with rapidly changing technology (Muzio 1999). Providing opportunities to complete online graduate degrees will enhance the opportunities for these mid-career learners the opportunity to work and go to school (Bartolic-Zlomislic \& Bates 1999).

In a 1995 study, Dolence and Norris suggested that this upgrade of skills might need to take place, on average, every five to seven years. They predicted that by the year 2010, the full-time equivalent of one-seventh of the American workforce would be enrolled in higher education or retraining. If this prediction holds true, a current trend that is erasing traditional divisions between post-secondary institutions, the workplace, and government, will accelerate (Lewis, Smith, \& Massey 1999). In relation to retraining, the private sector has several advantages over publicly supported institutions, including their ability to address "short half-life knowledge" because they have the flexibility to respond to the marketplace and provide "just-in-time" training (Knight 1997). Denning (1996) agreed that private institutions tend to respond more quickly to declining enrolments compared to state-controlled institutions.

In order to move forward, post-secondary institutions need in many respects to reassess their core values in order to respond to the challenges that a knowledge society presents. Knight (1997) agreed that none of these challenges could be addressed without re-inventing and re-engineering the institution. Dill (1996) agreed that these changing demands would encourage institutions to clarify their priorities and to implement difficult choices. However, in order for any organizational change to have effect, it needs to occur at the institutional level. (Twigg, 1994) Creth (1996) suggested that having a strategic plan provides the clear direction and allows the flexibility to respond to challenges and opportunities as they occur.

\section{Preparing for the Challenges Ahead}

Lewis, Massey and Smith (2001) identified four areas as critical for post-secondary institutions to prepare for the challenges and opportunities that technology. These areas are: technology, technical and pedagogical support, policies and policy processes and strategic planning. These provide a framework of what I believe is necessary for institutions to integrate technology more fully in the classroom (whether physical or virtual). 


\section{Technology}

This section addresses issues surrounding networking capabilities, minimum hardware and software configurations for faculty, student-owned computing programs, a method for tracking and accounting for information technology (IT) costs, and a technology strategy that addresses regular upgrading and replacement of equipment.

\section{Technical and Pedagogical Support}

The need for support increases in a technological environment, and issues surrounding faculty development in technology and pedagogy, student support and training, and curriculum design expertise are critical to the successful integration of technology.

\section{Policies and Policy Processes}

It is recommended that a transparent process be established to address the use of technology in education, the identification of institutional priorities for technology, faculty rewards and incentives, promotion and tenure policies, intellectual property, promotion of partnerships, and transfer credit arrangements.

\section{Strategic Planning}

Strategic planning is an essential and on-going process. It is recommended that strategic planning include the integration of educational technology goals with institutional goals, identification of learner needs that could be met with technology, identification and the use of market research to match institutional strengths with potential opportunities, especially for integrating technology.

Further, we are informed by the movement towards a knowledge society which has created an audience of learners who are more discerning about how they learn, what they learn, and when they learn it. (Knight, 1997) Therefore, as we move forward we need to remember two valuable pieces of advice from Ford and Bates. Ford (1996) reminds us that developing and implementing a strategic plan for educational technology is often a difficult and complex process, and, from Bates (2000) that the plan refers to both the technological infrastructure and the manner that technology will be adapted in the teaching and learning environment. By taking the above factors into account we help ensure the successful integration of ICT, as each provide a balance between jumping on the latest bandwagon and planning for the future.

\section{Integration}

There is a concern about institutions "jumping on the technology bandwagon" and developing ineffective or poor quality online courses (Bates, Harrington, Gilmore, \& van Soest 1993, 137). Savery and Duffy (1995) suggested the following four principles 
be applied to ensure effective online courses: (1) learning is an active and engaged process, (2) learning is a process of constructing knowledge, (3) learners function at a meta-cognitive level, and (4) learning involves "social negotiation." This corresponds with Sliwa (1994) who recommends that for post-secondary institution to remain viable, they need to develop ways to provide educational opportunities that are preferred by the individual learner and not formatted in the traditional manner.

To address these issues, Bates (2000) recommends that new teaching methods need to be developed as instructors use multimedia learning to facilitate higher order thinking. However, a concern of integrating technology in the classroom is the tendency to teach specific types of technology rather than the problem solving skills of when to use the technology (Kearsley 1998). Sliwa (1994) provided a suggestion to overcome this problem, "new technology should be used to enable faculty to pursue creative teaching methods and to provide opportunities for improved learning experiences." Bates $(1996,1997)$ suggested the instructor be given the opportunity to experiment with new technology.

With this in mind, we argue that information technology can no longer be viewed as an "adjunct" or "add on" to an institution's other activities. The principle of integration, therefore, involves developing and supporting initiatives aimed at weaving information technology into the substantive fabric of the institution's academic, professional, and administrative activities. Such initiatives would provide both incentives for innovation and disincentives for stagnation.

Specific recommendations include:

- Purchasing technology as necessary for teaching rather than buying technology that we think might be useful,

- Completing a survey/needs assessment (or finding one already completed) that addresses issues relating to market needs of the institution.

- Ensuring that faculty are provided with appropriate instructional and technical design support to develop and integrate technology in their classes effectively.

- Bringing technology to the class rather than in a lab-setting.

- Understanding that faculty and staff need to work together to achieve the goals of integration.

These initiatives would need to be carefully developed as the research literature shows there to be formidable structural, cultural, and territorial resistance in organizations, especially universities, to dealing meaningfully with the imperative to change - resistance that is putting some universities in a competitively disadvantageous position with regard to instructional delivery when compared with the colleges (who are typically more able to respond to market demand) and the private sector. 


\section{Reorganization of Existing Support}

Can organizational and administrative arrangements that evolved in an environment in which ICT played a compartmentalized, supplemental role in the institution's academic and professional life adequately support the transition to an environment in which ICT becomes an integral component within those activities? Can the roles and responsibilities of ICT support personnel that were designed to address compartmentalized, supplemental needs adequately support the transition to newer, more integrated environments?

As uncomfortable and unsettling as it may be the answer to both questions is clearly "no." The principle of decentralization, therefore, may be understood as the structural and organizational correlative to the principle of integration. As such it deals with developing and supporting the reorganization of ICT support services and the reconceptualization of the roles and responsibilities of ICT support personnel. As with integration, these initiatives will need to be developed very carefully and with great sensitivity to the effects such changes will have on the individuals concerned.

Some elements of an optimally configured ICT support service would include

- Developing individual personnel as ICT “primes” in key regions of the institution's activities. Each prime would thereby become a member of a functioning academic or administrative operation and would participate directly with faculty and administrators in meeting their needs,

- Budgeting and planning for ICT should be folded into the appropriate academic or administrative operating budget and planning process,

- Development, review, and evaluation of ICT policy would be the responsibility of the institution's Senate or Council,

- Maintaining general, all-purpose computing labs is not only costly but anachronistic. These labs should be phased out, more or less gradually, and students should be required to provide their own hardware. A fairly detailed implementation plan should be developed for the transitional period as change on this scale is bound to be unsettling. A limited student hardware assistance program should be developed and implemented for students with special needs.

- As all purpose labs are phased out, the institution should invest its new equipment funds in creating and supporting dedicated labs and "connected" classrooms. These sites should be attached to pertinent academic or administrative operations each of which could have ICT "primes." Every effort should be made to keep these sites as up-to-date as possible and therefore an intentional equipment "downgrade" plan should be developed. As equipment is upgraded existing hardware should be made available for other institutional uses - including faculty, staff, and student assistance program use - before being discarded.

To move forward in this direction, an investment into the technological infrastructure and policy development needs to occur. Green (1995) made the observation that insti- 
tutions cannot afford to "build or maintain a technological infrastructure on year-end funds or 'budget dust'." This is a critical step for the institution to undertake. However, reallocating resources is not enough and issues surrounding support and training need to be addressed. Noblitt (1997) argued that there appears to be a mythology surrounding information technology that places emphasis on the technology. He stated "that it's actually all about managing change - technical, social, pedagogical, political and financial."

\section{Professional Development}

The need for adequate technology and instructional support as a prerequisite for success has been stressed throughout the literature (e.g., Palloff \& Pratt 1999; Kearsley 1998, Bates 2000) and we feel that it is important for an institution to continue to provide and advance support in this area. Bates (2000) argues that there is a need to develop methods that ensure all members of the academic community have access to support and encouragement to use educational technologies. This encourages teaching with technology to become part of the mainstream on-campus instead of being reserved for early adopters and innovators. Further, he stressed the importance of addressing issues for promotion and tenure, workload, and training for faculty in using technology.

Faculty members need to learn both how to use the technology and also why they are using it in order for technology to be effective in their courses. Frayer (1999) more specifically recommended four strategies that were employed at Duquesne University that encouraged faculty to think critically about pedagogy within technology. The first strategy was based on an exemplar approach where the faculty member was encouraged to learn about the successful technology practices of others. This was accomplished through teaching with technology fairs, lunch "bytes," live teleconferences, and teaching workshops.

In the second strategy, faculty members were asked to think reflectively on their goals for students and to determine how the technology could help them meet those goals. At Duquesne they held (a) an online course about online teaching and learning, (b) a summer institute about teaching with technology, (c) teaching, learning and technology roundtables. Notably, they integrated the technology across the curriculum.

The third strategy provided opportunities for faculty members to learn about what technologies were available on-campus that could best meet their teaching needs. They were also provided information on technologically-enhanced pedagogical strategies. To accomplish this, a variety of methods were used including: (a) book study groups, (b) new faculty orientations, (c) early summer workshops, (d) lunch bytes, (e) faculty development studios, and (f) newsletters.

The last strategy was to reward faculty for their successful use of educational technology. Several ways recommended for accomplishing this included (a) promotion and tenure issues, (b) awards for innovation excellence in teaching, learning and technology, and (c) newspapers articles (Frayer, 1999). 


\section{Conclusions}

Rossner and Stockley (1997, pp. 334-335) provided a series of requirements that could be used as a template to ensure the successful implementation of the strategic plan for educational technology. These requirements include:

- assurance of support from the senior administrative level;

- the commitment to put in place an easily accessible campus-wide technology "backbone" that supports Web-based instruction within and beyond the campus;

- extending current library facilities to include the online library;

- designing a system that allows students to register via the Web;

- designing a system that allows faculty and students to access any campus-based server containing information relative to their work;

- supporting researchers experimenting with hardware, software, and models of instruction that enhance Web-based teaching and learning;

- developing a process for continuous feedback between faculty and administration

- technical people with Web expertise;

- developing support systems that provide training in the educational uses of interactive technologies;

- providing on-going technical and pedagogical support for faculty and students working on the Web; and

- committing adequate, long-term base budget financial support for Web-based instruction.

It is important also to remember that the role of information communication technology is to enhance learning, teaching, research, and administration; learning is augmented through information technologies that promote effective, stimulating, and accessible learning environments. Teaching can be revitalized through technologies which explore creative and dynamic classroom interactions that enable and further develop sound pedagogical goals. Research is aided by technologies through the collection, manipulation, representation, and dissemination of data. Administrative operations are supported by technologies in the maintenance of institutional data including student records and human and physical resources.

\section{References}

Association of Universities and Colleges of Canada. 2005. Directory of Canadian universities. Ottawa: AUCC Publications.

Bartolic-Zlomislic, S., \& Bates, A. W. 1999. Investing in online learning: Potential benefits and limitations. Canadian Journal of Communications, 24: 349-366. 
Bates, A. W. 1996. The impact of technological change on open and distance learning. Keynote address presented at Queensland Open Learning Network, Brisbane, Australia, December 1996.

Bates, A. W. 1997. Restructuring the university for technological change. Paper presented the Carnegie Foundation for the Advancement of Teaching - What Kind of University, London, England, January 1997.

Bates, A. W. 2000. Managing Technological Change: Strategies for College and University Leaders. San Francisco: Jossey-Bass.

Bates, A. W., Harrington, R., Gilmore, D., \& vanSoest, C. 1993. Compressed video and video conferencing in open and distance learning: A guide to current developments. In D. Black (Ed.), Distance Education in British Columbia: Selected Papers and Case Studies. Vancouver, BC: Open Learning Agency: 117-139.

Benjamin, R., Carroll, S., Jacobi, M., Krop, C. \& Shires. M. 1993. The Redesign of Governance in Higher Education. Santa Monica: Rand's Institute on Education and Training.

Bruce, R. 1999. Educational Technology Planning. Victoria, BC: Centre for Curriculum, Transfer and Technology.

Clark, R. E. 1983. Reconsidering research on learning from media. Review of Educational Research, 53:445-459.

Clark, R. E. 1994a. Media and method. Educational Technology Research and Development, 42: 7-10.

Clark, R. E. 1994b. Media will never influence learning. Educational Technology Research and Development, 42: 21-29.

Creth, S. D. 1996, September). The electronic library: Slouching toward the future or creating a new information environment. Paper presented at the Follett Lecture Series, London, England. Available: http://www.ukoln.ac.uk/services/papers/follett/creth/paper.html

Dalton, D. W. 1989. Computers in the schools: A diffusion/adoption perspective. Educational Technology, 29: 20-27.

Denning, P. J. 1996. Business designs for the new university. Educom Review, 31: 20-30.

Dill, D. D. 1996. Academic planning and organizational design: Lessons from leading American universities. Higher Education Quarterly, 50: 35-53.

Dolence, M. G., \& Norris, D. M. (1995). Transforming Higher Education: A Vision for Learning in the 21st Century. Ann Arbor: Society for College and University Planning.

Duderstadt, J. J. 1997. The future of the university in an age of knowledge. Journal for Asynchronous Learning Networks, 1(2). Available:

http://www.aln.org/publications/jaln/v1n2/pdf/v1n2_duderstadt.pdf

Ford, P. 1996. Information strategies: A UK perspective. Proceedings of the Institutional Management in Higher Education. Paris, France, 147-155.

Green, K. G. 1995. Paying the digital piper. Change, 27: 53-54.

Kearsley, G. 1998. Educational technology: A critique. Educational Technology, 38: 47-51.

Knight, P. T. 1997. The half-life of knowledge reform of the education sector for the global knowledge-based economy. Paper presented at the Forum on Education in the Information Age, Cartagena, Colombia, July 1997.

Lewis, B., Massey, C., \& Smith, R. 2001. The Tower Under Siege. Montreal: McGill-Queen's University Press.

Lewis, B., Smith, R., \& Massey, C. 1999. Mirroring the networked society: Government policy, higher education, and telelearning technology in Canada. Canadian Journal of Communication, 24: 319-336.

Muzio, J. 1999. The development of a prototype learner-centred electronic distributed learning course for Royal Roads University. Unpublished doctoral dissertation, Nova Southeastern University, Florida.

Noble, D. F. 1997. The religion of technology. In Muzio, Rhynas, J.E., Williams, D. \& Moore, E. (Eds.) Leading Edge Training Technologies. Victoria, BC: University of Victoria: 4-7. 
Noblitt, J. S. 1997. Top-down meets bottom-up. Educom Review, 32: 38-43.

Palloff, R. M. \& Pratt, K. 1999. Building Learning Communities in Cyberspace: Effective Strategies For the Online c Cassroom. San Francisco: Jossey Bass.

Poole. G. 1997. Back to the future: What can we learn from current debates on educational technology? Journal of Distance Education, 12: 9-13.

Rogan, J., Odansz, F., Robinson, L, \& Baumann, C. 1996. Reach for the sky, Western Montana College. Paper presented at the meeting of the American Educational Research Association, New York City, NY.

Rossner, V., \& Stockley, D. 1997. Institutional perspectives on organizing and delivering web based instruction. In B. Kahn (Ed.), Web-Based Instruction. Englewood Cliffs, NJ: Educational Technology Publications: 333-336.

Savery, J. R., \& Duffy, T. M. 1999. Problem based learning: An instructional model and its constructivist framework. Educational Technology, 35: 31-38.

Samuels, B. 1996. A day in the life of a change agent. Educom Review, 31: 12-16.

Slack, J. D. 1994. The university's technology policy. Academe, 80: 37-41.

Sliwa, S. 1994. Re-engineering the learning process with information technology. Academe, 80: 8-12.

Stockley, D. 2004. Strategic planning for technological innovation in Canadian post secondary education. Canadian Journal of Learning Technology, 30: 113-124.

Twigg, C. A. 1994. Navigating the Transition. Educom Review, 29: 21-24. 